\title{
The Use of Modified Beetroot Fibers by Sodium Dodecyl Sulfate (SDS) Cleaning Water Contaminated by Organic and Inorganic Compounds
}

\author{
Jamil Rima ${ }^{1}$, Kamil Rahme ${ }^{2}$ \& Karrine Assaker ${ }^{1}$ \\ ${ }^{1}$ Physical Chemistry of Environmental Engineering and Biology Fanar, Lebanese University Faculty of Sciences \\ II, Fanar, Lebanon \\ ${ }^{2}$ Faculty of Natural and Applied Sciences, Notre Dame University (NDU) Louaize, Zouk Mosbeh, Lebanon \\ Correspondence: Jamil Rima, Chemistry of Environmental Engineering and Biology Fanar, Lebanese University \\ Faculty of Sciences II, Fanar, Lebanon. Tel: 961-332-1833. E-mail: jamil.rima1@gmail.com
}

\author{
Received: April 28, 2014 Accepted: June 14, 2014 Online Published: June 17, 2014 \\ doi:10.5539/jfr.v3n5p19 URL: http://dx.doi.org/10.5539/jfr.v3n5p19
}

\begin{abstract}
The beetroot fibers were used to decontaminate water polluted by methylene blue dye (MB), to remove heavy metals from wastewater and to soften hard water. In order to improve the adsorbent performance and to determine the optimum conditions of industrial wastewater cleaning, the effect of fiber particle sizes, initial concentrations of pollutants, $\mathrm{pH}$ of aqueous solutions and effluent rates on the cleaning procedure were investigated. Data showed that the efficiency of cleaning increased when fiber particle size decreased (from $\mathrm{mm}$ to $\mu \mathrm{m}$ scale). Optimum $\mathrm{pH}$ value for adsorption was 6 to 6.5. Maximum metal cations retention or hardness of modified fibers by sodium dodecyl sulfate (SDS) was estimated at $70 \mathrm{mg}$ per gram of fiber; while the maximum retention of methylene blue was found to be $300 \mathrm{mg}$ of dye per gram of fiber. Chemical modification of fibers by an anionic surfactant such as sodium dodecyl sulfate increased the efficiency of the dye elimination by 2-fold when compared to unmodified fibers. The adsorption parameters were determined using Langmuir and Freundlich isotherms.
\end{abstract}

Keywords: modified beetroot fibers, sodium dodecyl sulfate, heavy metals, hard water softening, methylene blue, adsorption isotherm

\section{Introduction}

Dyes have been extensively used in dyeing paper and pulp, textiles, plastics, leather, cosmetics and food industries (Gulnaz, 2004). The colored compounds are not only visually displeasing when present in water streams but they can also inhibit sunlight penetration into the stream and affect aquatic ecosystems (Tsai, 2001). These dyes such as methylene blue (MB) are also harmful to aquatic life. MB dye causes eye burns, which may be responsible for permanent injury to the eyes of human and animals. By inhalation, it can give rise to short periods of rapid or difficult breathing, while ingestion through the mouth produces a burning sensation and may cause nausea, vomiting, profuse sweating, mental confusion, painful micturition, and methemoglobinemia (Ghosh, 2002; Feng, 2012).

Removing color from wastewater can be done via several traditional biological and physico-chemical methods (Addaou, 2012; Chern, 2001; Robinson, 2002; Gupta, 2000; Janos, 2003). Chemical methods use coagulation or flocculation (Orfao, 2006), combined with flotation and filtration. Precipitation - flocculation, electroflotation, electrokinetic coagulation and ozonation to remove color (Maurya, 2008). Several alternative biological methods have also been used for the adsorption of dyes from aqueous solutions. For instance, the invasive brown seaweed Sargassum muticum algae (Eugenia, 2005), the marine green Ulva When research is driven by the desire to resolve controversial issues, all sides in the debate should be lactuca algae (Mikati, 2013), and Chara aspera algae (Low 1994), have been tested for removal of methylene blue from aqueous solutions.

Various treatment systems have been developed using activated carbon as adsorbent (Hatt, 2013). Researchers have studied the production of activated carbon from palm-tree cobs (Feng, 2012), plum kernels (Tseng, 2003), cassava peel (RajeshWarisivaraj, 2001), bagasse (Tsai, 2001), jute fiber (Senthilkumaar, 2005), rice husks (Yalcin, 2000), olive stones (El-Sheikh, 2009), date pits (Girgis, 2002), fruit stones and nutshells (Aygun, 2003), and also bamboo activated with potassium hydroxide $(\mathrm{KOH})$ and carbon dioxide $\left(\mathrm{CO}_{2}\right)(\operatorname{Tan}, 2008)$. As for the 
heavy metals removal from wastewater, several studies were carried out and highlighted that the biosorption of metal cations mainly depends on the interactions of metals with specific groups displayed on the biosorbent surface (Kratochvil, 1998; Bai, 2001).

In the present work, the efficiency of a new beet fiber based biofilter modified with hydrophobic chains of sodium dodecyl sulfate (SDS) was evaluated contaminated water. A dual role of the modified filter was studied; the first was its effectiveness in eliminating heavy metals and softening hard water via positive and negative charges of chemical functions and the second lies in its utility in removing organic compounds, such as dyes, by the hydrophobic chains of SDS.

\section{Method}

\subsection{Preparation of Fibers}

Beetroot fibers used were collected from different agricultural areas of Lebanon, processed, purified and used to synthesize the modified biofilter. The collected fibers were cut into small pieces, air-dried and powdered in a grinder. The samples obtained were first sieved through a $100 \mu \mathrm{m}$ sieve and then through a $50 \mu \mathrm{m}$ sieve, then soaked in distilled water for 24 hours at room temperature. Once washed by distilled water, fiber powder was air-dried with $\mathrm{T}_{\text {air }}$ of $100^{\circ} \mathrm{C}$, and then stored until use. Double distilled water was used in all solutions. Modified fibers were prepared as follows: twenty grams of fibers were transferred into a beaker $500 \mathrm{ml}$ containing $100 \mathrm{ml}$ of aqueous SDS (Fischer Scientific Co.) salt solution with $2.9 \mathrm{~g} / 1(\sim 0.01 \mathrm{~mol} / \mathrm{l})$. The mixture was then heated at $50{ }^{\circ} \mathrm{C}$ and stirred for 4 hours. After filtration through a whatman $0.45 \mu \mathrm{m}$ filter, fibers were washed by distilled water several times then air-dried with $\mathrm{T}_{\text {air }}$ of $100^{\circ} \mathrm{C}$ for 24 hours.

\subsection{Column Procedures to Remove Dyes, Total Dissolved Solid (TDS) and Heavy Metals}

The column consisted of a plexiglass tube $(30 \mathrm{~cm}$ height, $4.0 \mathrm{~cm}$ of diameter) perforated at the bottom and connected to a pumping system. In order to assure homogeneity and reproducibility of the results, the column was filled with $20 \mathrm{~g}$ of fibers and compressed until getting a density of $0.4 \mathrm{~g} / \mathrm{cm}^{3}$. The flow rate of liquid was adjusted to 4 GPM (gallons per minute) at a pressure of 15 PSI. $50 \mathrm{ml}$ of polluted water was transferred into the biomass filter. The same operation was repeated ten times using the same initial solution in the objective to reach the saturation of fibers by pollutants. Solutions of methylene blue (Sigma Aldrich) with different concentrations (1000 ppm, $300 \mathrm{ppm}, 200 \mathrm{ppm}, 100 \mathrm{ppm}$ and $50 \mathrm{ppm})$ and heavy metal solutions $\left(\mathrm{CuSO}_{4} \cdot 5 \mathrm{H}_{2} \mathrm{O}, \mathrm{NiSO}_{4} \cdot 6 \mathrm{H}_{2} \mathrm{O}\right.$, $\mathrm{Pb}\left(\mathrm{NO}_{3}\right)_{2}, \mathrm{ZnCl}_{2}$ (Prolabo)) prepared at different concentrations (1000 ppm, $200 \mathrm{ppm}$ and $100 \mathrm{ppm}$ ) were transferred into the filter and tested. The $\mathrm{pH}$ values were adjusted to an ideal $\mathrm{pH}$ of 5-6 corresponding to the maximum of retention as shown in the figure 1 by the addition of aqueous $\mathrm{HCl}$ (Prolabo).

\subsection{Instruments and Methodology}

Metals were analyzed by atomic absorption spectrometry (Perkin Elmer 5000 and Shimadzu A-6800), where the corresponding lamp ( $\mathrm{Zn}, \mathrm{Cu}$ and $\mathrm{Pb}$ ) was selected for each metal. TDS were measured using Oakton CON 11 handheld conductivity TDS meter. UV absorption measurements were performed on a Shimadzu using $10 \mathrm{~mm}$ quartz cuvette cells. Concentrations of MB in solutions were determined, before and after adsorption by a double beam UV spectrophotometer (Shimadzu, Japan) at $665 \mathrm{~nm}$. The Infra Red (IR) spectrum was recorded on a Fourrier Transform Infra Red (FTIR) spectrometer (UNICAM). The surface area of the polymer samples was determined by nitrogen physisorption measurements. Nitrogen adsorption-desorption isotherms were obtained at $77 \mathrm{~K}$, over a wide relative pressure range from 0.01 to 0.999 , with a volumetric adsorption analyzer TRISTAR 3000 manufactured by Micromeritics. The samples were degassed under vacuum for several hours at $60{ }^{\circ} \mathrm{C}$ before nitrogen adsorption measurements.

\section{Results}

\subsection{Beetroot Chemical Composition}

The average percentage of different components of beetroot fibers are respectively $25 \%$ of cellulose, $5 \%$ of lignin, 30\% pectin, and 40\% hemicelluloses (Dinand 1996). The materials contain several chemical functional groups like hydroxyl, carboxylic, aldehyde, ketone, $\mathrm{C}=\mathrm{N}$. Functional groups played an important role in grafting SDS molecules and also in adsorbing and complexing heavy metals on fibers surface.

\subsection{Grafting SDS Chains on the Surfaces of Beetroot Fibers}

Modified fibers were prepared as follows: twenty grams of fibers were transferred into a beaker $500 \mathrm{ml}$ containing $100 \mathrm{ml}$ of aqueous SDS (Fischer Scientific Co.) salt solution with $2.9 \mathrm{~g} / 1\left(\sim 0.01 \mathrm{~mol} \mathrm{l}^{-1}\right)$. The mixture was then heated at $50^{\circ} \mathrm{C}$ and stirred for 4 hours. After filtration through a whatman $0.45 \mu \mathrm{m}$, fibers were washed by distilled water several times then air dried with $\mathrm{T}_{\text {air }}$ of $100^{\circ} \mathrm{C}$ for 24 hours. The new materials obtained were 
analyzed by FTIR spectrometer. The changes were attributed to grafted SDS chains on the surface of fibers. (Table 1).

Table 1. Summary of wavelengths from FTIR spectra of modified and unmodified beetroot fibers

\begin{tabular}{lcc}
\hline No Of lines & $\begin{array}{c}\text { Unmodified beetroot fibers } \\
\text { wavenumbers }\left(\mathrm{cm}^{-1}\right)\end{array}$ & $\begin{array}{c}\text { modified beetroot fibers } \\
\text { wavenumbers }\left(\mathrm{cm}^{-1}\right)\end{array}$ \\
\hline 1 & 3523 & 3523 \\
2 & 3397 & 3364 \\
3 & 3282 & 3282 \\
4 & 2920 & 2926 \\
5 & 1701 & 1731 \\
6 & 1638 & 1627 \\
7 & 1616 & ----- \\
8 & 1430 & 1430 \\
9 & 1243 & 1320 \\
10 & 1239 & 1239 \\
11 & 1106 & 1139 \\
12 & ---- & 1101 \\
13 & 1057 & 1046 \\
\hline
\end{tabular}

\subsection{Effect of pH on the Retention Efficiency of Cations and Dyes}

In order to study the effect of $\mathrm{pH}$ on the retention efficiency of fibers, we prepared for each metallic cation $\mathrm{Pb}$, $\mathrm{Cu}$ and $\mathrm{Zn}$, triplicate solutions at the same concentration $(200 \mathrm{ppm})$ with $\mathrm{pH}$ values varying from 1.5 to 6.5 . Furthermore, we tested the retention efficiency for TDS (total dissolved solid) Figure 1 shows that metallic cations are more easily removed with the $\mathrm{pH}$ increase. The percentage of retention regularly increased to reach a maximum at $\mathrm{pH} 6.5$ with the following values: $100 \%$ for lead, $99 \%$ for zinc, $98 \%$ for copper and $99 \%$ for TDS of hard water.



Figure 1. Effect of $\mathrm{pH}$ on removal efficiency of heavy metals (measurements were performed in triplicates) 
While, to study the influence of $\mathrm{pH}$ on the efficiency of beetroot fibers in removing dyes, we filtered solutions of methylene blue (100ppm) through the fibers at variable $\mathrm{pH}$ ranging from 1.5 to 7 . Solutions were filtered through biofilters under the same conditions regarding mass of the filter and same volume of the methylene blue solutions. Optimum $\mathrm{pH}$ for the maximum of removal was 6.5

\subsection{Retention Efficiency of Beetroot Fibers for Cationic Model Solutions}

The modified fibers were first tested to remove some metallic cations from a model solution, a mixture of lead, zinc, nickel and copper cations. The total concentration was $200 \mathrm{ppm}$ (50 ppm of each). Figure 2 shows that after 10 passages, the retention efficiency of the modified fiber varied from: $100 \%$ to $96 \%$ for lead, $99 \%$ to $96 \%$ for zinc, $99 \%$ to $85 \%$ for copper and from $99 \%$ to $77 \%$ for nickel. The beetroot fibers have proven their ability to remove various heavy metals. Additional tests were conducted for softening hard water, which showed a removal efficiency of the hardness exceeding $97 \%$ for TDS $=400 \mathrm{ppm}$. Since modified fibers were prepared to improve the removal capacities for the organic compounds, it will be applied on the removal of dyes from wastewater. In addition, effect of the sizes of beetroot fibers will be studied in order to optimize the best conditions for wastewater treatment.

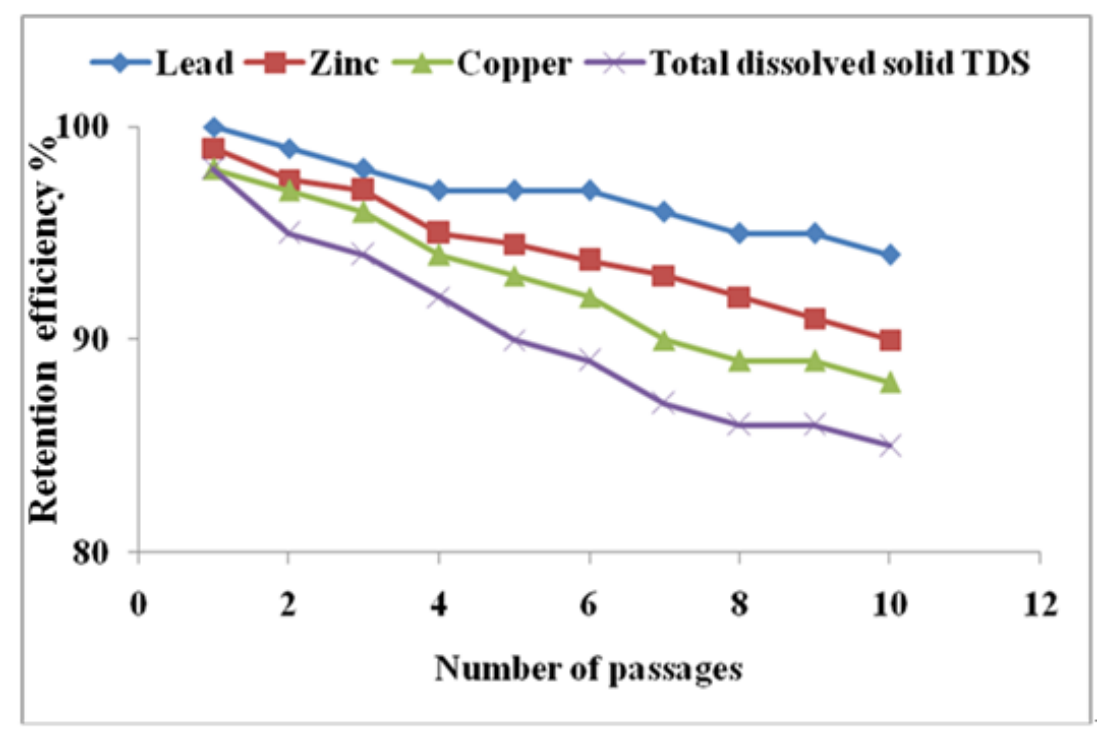

Figure 2. Retention efficiency of the modified fiber for lead, zinc, copper and TDS with the number of passages

\subsection{UV-visible Absorption Spectra of Methylene Blue Solution (100 Ppm), Filtered by Unmodified and Modified Beetroot Fiber}

The efficiency of the modified fibers was tested by filtration of water polluted by methylene blue at the concentration of $100 \mathrm{ppm}$ and comparison of the results between modified and unmodified fibers. The UV Spectrum of the initial concentration shows a maximum of absorption at $\lambda_{\max }=665 \mathrm{~nm}$ and an absorbance $\mathrm{A}=$ 1.11. Fifty $\mathrm{ml}$ of methylene blue were filtered through $20 \mathrm{~g}$ of beetroot fibers $(50 \mu \mathrm{m})$ modified and unmodified and UV absorption spectra were recorded before and after the filtration of solutions. Figure 3 presents the effect of modified fibers on the removal efficiency of methylene blue. As shown, the unmodified fibers reduced $85 \%$ of methylene blue from solution at $100 \mathrm{ppm}$ of concentration, while the modified fiber was able to remove more than $99 \%$. 


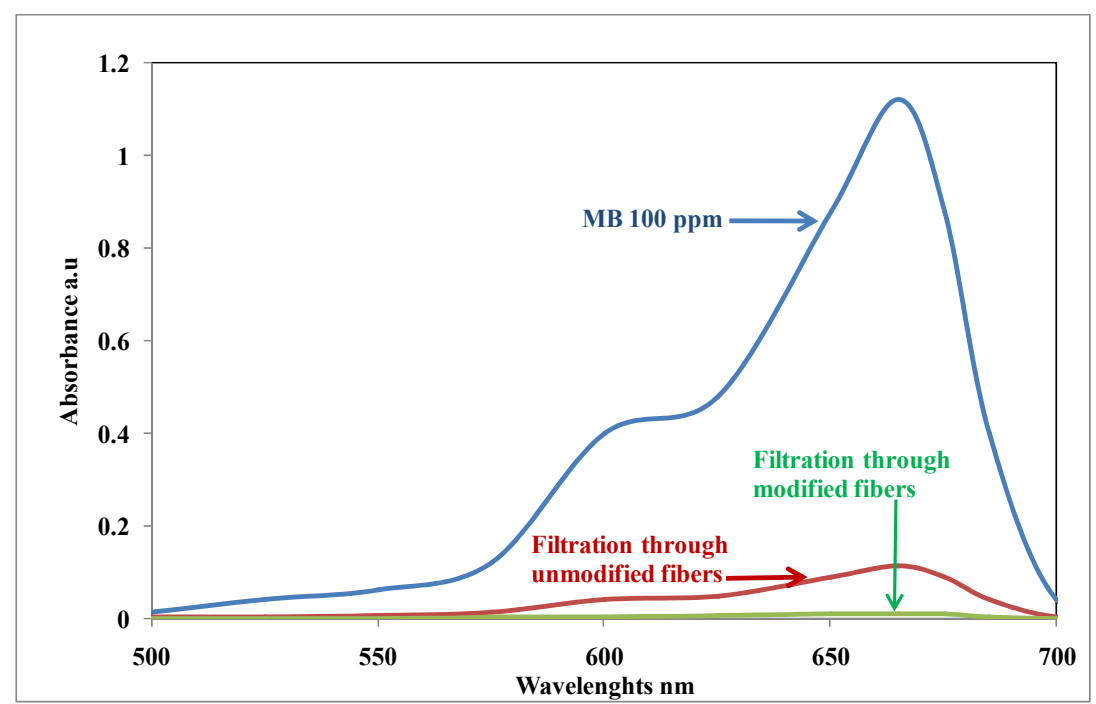

Figure 3. Effect of SDS chain on the efficiency of modified fibers

\subsection{Effect of Initial Concentration on the Removal Efficiency of Methylene Blue From Wastewater Using Modified Fibers}

A series of filters consisting each of $20 \mathrm{~g}$ of modified fiber by SDS, were ground to $50 \mu \mathrm{m}$, and packed into plexiglass cylinders. $50 \mathrm{ml}$ of methylene blue solutions from a mother solution $1000 \mathrm{ppm}$ were transferred into each of those cylinders to perform the filtration. Concentrations of methylene blue solutions used for this test varied between $50 \mathrm{ppm}$ and $1000 \mathrm{ppm}$. The absorption spectra of UV-Vis solutions for all solutions before and after filtration were determined to evaluate the influence of initial concentrations on the retention capacities of the filtering system. Figure 4 shows that the removal efficiency was significantly remarkable, and it is estimated to be more than $99 \%$ for methylene blue having concentrations less than $750 \mathrm{ppm}$ and $96 \%$ for concentration of $1000 \mathrm{ppm}$. Similar experiments were repeated with unmodified fibers in order to provide evidence on the effect of the hydrophobic SDS chains attached to fibers in removal of dyes. The results showed undoubtedly that the unmodified fibers used to clean polluted waters by the methylene blue were less efficient in cleaning of polluted water.

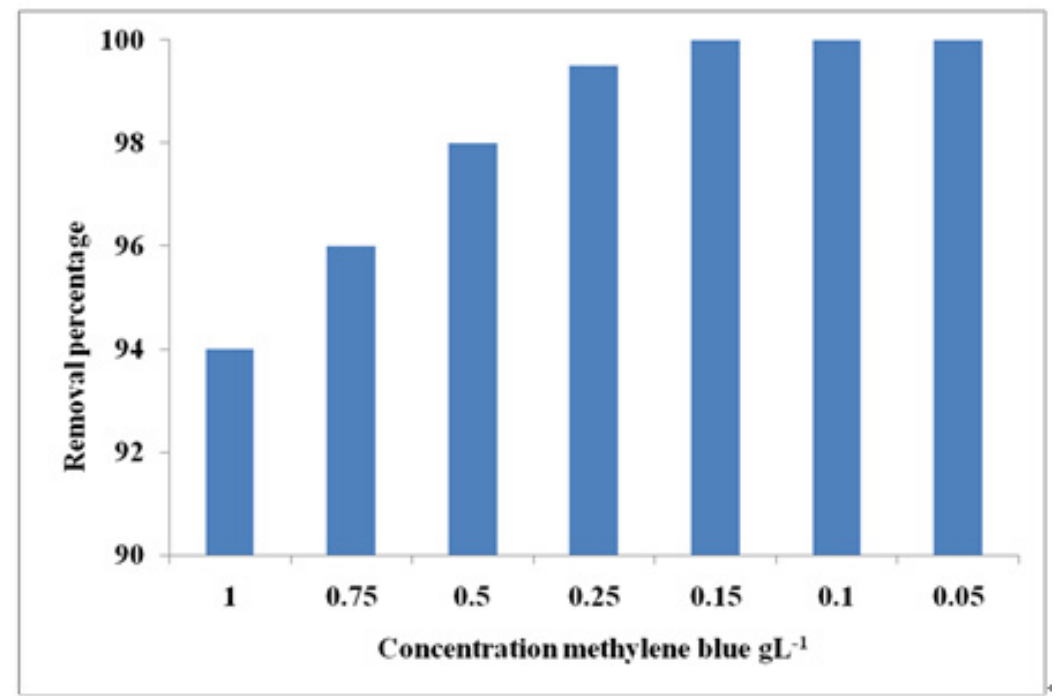

Figure 4. Effect of initial concentration on the removal efficiency of methylene blue

\subsection{Effect of Fibers Size on Methylene Blue Removal Efficiency}

For this objective, solutions of $1000 \mathrm{ppm}$ methylene blue have been passed through similar filters differing only by sizes. Modified beetroot with dimension in $\mathrm{mm}$ scale (XL mm, $0.5-1 \mathrm{~mm}$ ), $100 \mu \mathrm{m}$ and $50 \mu \mathrm{m}$ were tested to 
determine the fibers saturation in function of the loaded volume. Results of retention efficiency in function of fibers with different sizes are shown in Figure 5. Data showed that the retention efficiency was inversely proportional to fiber size. Elimination of $1000 \mathrm{ppm}$ methylene blue was $85 \%$ with XL (mm) and reached $97 \%$ with the $100 \mu \mathrm{m}$ fibers.



Figure 5. Retention efficiency in function of fibers with different sizes

Table 2 illustrates the retention efficiency of the modified fibers according to the loaded volume and the size of fibers.

Table 2. Removal efficiency of methylene blue (1000 ppm) by modified and unmodified fibers at different sizes (XL mm, $100 \mu \mathrm{m}$, and $50 \mu \mathrm{m}$ )

\begin{tabular}{cccc}
\hline Number of passages & $\begin{array}{c}\text { \% Removal of dye by } \\
\text { modified fibers (XL mm) }\end{array}$ & $\begin{array}{c}\text { \% Removal of dye by } \\
\text { modified fibers }(100 \mu \mathrm{m})\end{array}$ & $\begin{array}{c}\text { \% Removal of } \\
\text { dye by modified } \\
\text { fibers }(50 \mu \mathrm{m})\end{array}$ \\
\hline 1 & 95 & 97 & 99 \\
2 & 93 & 92 & 98.5 \\
3 & 92 & 90 & 98 \\
4 & 90 & 84 & 97.5 \\
5 & 85 & 87 & 97 \\
6 & 83 & 90 & 96 \\
\hline
\end{tabular}

\subsection{Effect of Residence Time on the Retention Effectiveness}

Two methods of filtration were performed using modified fibers with a mass equal to $20 \mathrm{~g}$ and sizes of $100 \mu \mathrm{m}$. A volume of $50 \mathrm{ml}$ of $1000 \mathrm{ppm}$ methylene blue mother solution was filtered through the filter described below, either by free filtration $\tau_{\text {free time }}=20 \mathrm{~min}$ or by forced filtration using a special pump $\tau_{\text {forced time }}=1$ minute. The UV-Vis spectra of solutions were analyzed before and after filtration in both systems. Figure 6 shows that the retention efficiency of methylene blue was remarkably higher when the filtration was a free time operation. 


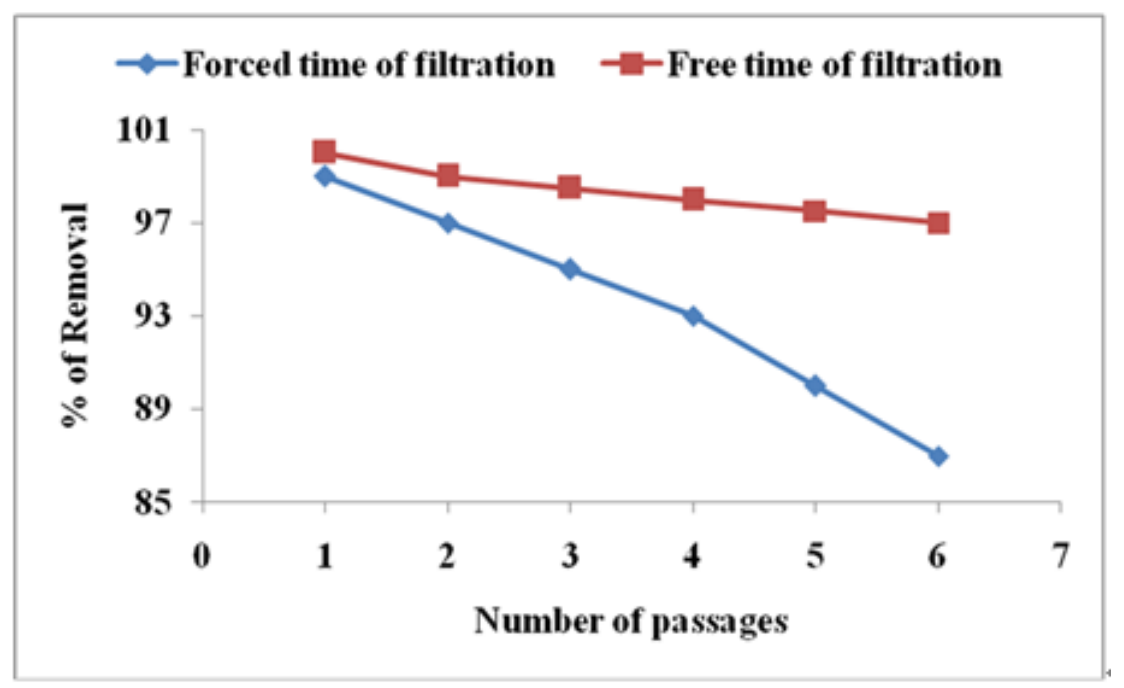

Figure 6. Effect of residence time on the retention effectiveness

\subsection{Nitrogen Adsorption-Desorption}

Nitrogen adsorption-desorption isotherms of the two samples (modified and unmodified beetroot fibers) (See supporting information $\mathrm{S} 3$ ). The specific surface area $\mathrm{S}_{\mathrm{BET}}$ and the constant $\mathrm{C}_{\mathrm{BET}}$ determined from the nitrogen adsorption data (BET method) are listed in table 3. Isotherms are not affected by the polymer nature since shapes of the two isotherms are quite similar. Nitrogen experiments performed on the two samples produced the same isotherms which could categorize samples into one group according to the IUPAC classification (Sing, 1985). Resulting adsorption-desorption isotherms had no hysteresis loop and exhibited "Type III" isotherm. The reversible type III isotherms have the representative form of isotherms obtained with nonporous or macroporous solids. In addition, they characterize weak gas/solid interactions, i.e. the surface interacts weakly with the adsorbent molecules. For this reason, the nitrogen. uptake remained low at a low relative pressure. Then, once a molecule is adsorbed, the adsorbate/adsorbate interactions will promote the adsorption of further molecules. Consequently, the resulting isotherms convert into convex form to the pressure axis.

Table 3. Nitrogen physisorption data of the samples. $\mathrm{C}_{\mathrm{BET}}$ is a constant related to the difference between the molar free energy of adsorption of the first layer and the liquefaction one

\begin{tabular}{ccc}
\hline Samples & BET surface area; $\mathrm{S}_{\mathrm{BET}}\left(\mathrm{m}^{2} / \mathrm{g}\right)$ & $\mathrm{C}_{\mathrm{BET}}$ \\
\hline Unmodified fibers & 2.6 & $<2$ \\
Modified fibers & 3.8 & $<2$ \\
\hline
\end{tabular}

The BET surface areas of the two materials are reported in Table 3. No significant change was detected in-BET surface area between the unmodified fibers $\left(\mathrm{S}_{\mathrm{BET}}=2-3 \mathrm{~m}^{2} / \mathrm{g}\right)$ and the modified $\left(\mathrm{S}_{\mathrm{BET}}=4 \mathrm{~m}^{2} / \mathrm{g}\right)$. The surface areas remained very low, thus the two samples are nonporous or, at least, macroporous. Obtained surface area values need to be compared with those of other catalyst materials. Typically, activated carbons should have a BET surface area higher than $500 \mathrm{~m}^{2} / \mathrm{g}$ (Garcia-Garcia 2003; Sricharoenchaikul, 2008; Rima, 2013), because as standard catalysts (or photocatalysts) used in water treatment display a surface area of the order of $200 \mathrm{~m}^{2} / \mathrm{g}$ (Blin, 2012; Zimny, 2012).

Furthermore, it is interesting to note that the hydrophobic behavior of the samples was highlighted by the very low value of the $\mathrm{C}_{\mathrm{BET}}$ constant $\left(\mathrm{C}_{\mathrm{BET}}<2\right)$. In fact, the $\mathrm{C}_{\mathrm{BET}}$ parameter gives an indication on the adsorbate/adsorbant interaction according to 


$$
C_{B E T}=\exp \left(\frac{E_{a d s}-E_{l i q}}{k T}\right)
$$

Where $E_{\text {ads }}$ is the energy of a molecule adsorbed in the first layer, whereas $E_{\text {liq }}$ is the adsorption energy in the other layers identified to the liquefaction energy. Determination of the $\mathrm{C}_{\mathrm{BET}}$ value has been proposed recently as a method to assess a surface polarity. The parameter $\mathrm{C}_{\mathrm{BET}}$ is high for polar surfaces and low for non-polar surfaces (Brunel, 2000; Trens, 2004). In the present study, the very low value of the parameter $\mathrm{C}_{\mathrm{BET}}$ emphasizes the large hydrophobic character of used materials. Specific surfaces of the samples of modified and unmodified fibers were determined by measurements of nitrogen physisorption. Low values of specific surfaces indicated that removal efficiency for heavy metals from-hard water TDS and dyes cannot be attributed to a specific surface

\subsection{Adsorption Isotherms}

Two important physiochemical aspects for the evaluation of the adsorption process as a unit operation are the equilibrium of the adsorption and the kinetics. Equilibrium studies evaluate the capacity of the adsorbent. The equilibrium relationships between adsorbent and adsorbate are described by adsorption isotherms, usually equivalent to the ratio of the quantity adsorbed to the one remaining in solution at a fixed temperature at equilibrium. There are two types of adsorption isotherms: Langmuir adsorption isotherms and Freundlich adsorption isotherms.

(a) Langmuir isotherm. The Langmuir adsorption isotherm is often used for adsorption of a solute from a liquid solution. The Langmuir adsorption isotherm is often expressed as

$$
\mathrm{Q}_{\mathrm{e}}=\mathrm{XmKC}_{\mathrm{e}} /\left(1+\mathrm{KC}_{\mathrm{e}}\right)
$$

Where, $Q_{e}$ is the adsorption density at the equilibrium solute concentration $\mathrm{C}_{\mathrm{e}}(\mathrm{mg}$ of adsorbate per $\mathrm{g}$ of adsorbent). $\mathrm{C}_{\mathrm{e}}$ is the concentration of adsorbate in solution $(\mathrm{mg} / \mathrm{L}) . \mathrm{Xm}$ is the maximum adsorption capacity corresponding to complete monolayer coverage ( $\mathrm{mg}$ of solute adsorbed per $\mathrm{g}$ of adsorbent). $\mathrm{K}$ is the Langmuir constant related to energy of adsorption ( $\mathrm{L}$ of adsorbent per $\mathrm{mg}$ of adsorbate). The above equation can be rearranged to the following linear form

$$
\mathrm{C}_{\mathrm{e}} / \mathrm{Q}_{\mathrm{e}}=1 / \mathrm{X}_{\mathrm{m}} \mathrm{K}+\mathrm{C}_{\mathrm{e}} / \mathrm{X}_{\mathrm{m}}
$$

The linear form can be used for linearization of experimental data by plotting $\mathrm{C}_{\mathrm{e}} / \mathrm{Q}_{\mathrm{e}}$ against $\mathrm{C}_{\mathrm{e}}$. Langmuir constants $\mathrm{X}_{\mathrm{m}}$ and $\mathrm{K}$ can be evaluated from the slope and intercept of linear equation.

(b) Freundlich isotherm. Freundlich isotherm is the relationship describing the adsorption equation and is often expressed as

$$
\mathrm{Q}_{\mathrm{e}}=\mathrm{K}_{\mathrm{f}} \mathrm{C}_{\mathrm{e}}^{1 / \mathrm{n}}
$$

where, $\mathrm{Q}_{\mathrm{e}}$ is the adsorption density (mg of adsorbate per $\mathrm{g}$ of adsorbent). $\mathrm{C}_{\mathrm{e}}$ is the concentration of adsorbate in solution $(\mathrm{mg} / \mathrm{L}) . \mathrm{K}_{\mathrm{f}}$ and $\mathrm{n}$ are the empirical constants dependent on several environmental factors and $\mathrm{n}$ is greater than one. This equation is conveniently used in the linear form by taking the logarithmic of both sides as:

$$
\mathrm{LnQ}_{\mathrm{e}}=\mathrm{LnK}_{\mathrm{f}}+1 / \mathrm{nLnC}_{\mathrm{e}}
$$

A plot of $\mathrm{LnC}_{\mathrm{e}}$ against $\mathrm{LnQ}_{\mathrm{e}}$ yielding a straight line indicates the confirmation of the Freundlich isotherm for adsorption. The constants can be determined from the slope and the intercept.

\subsubsection{Method Used for Adsorption Test}

The method used for the adsorption tests for different methylene blue concentrations is as follows: (1) $20 \mathrm{~g}$ of fibers as an adsorbent were transferred into a column and different concentrations of methylene blue were filtered through the column. (2) For each concentration, a volume of $500 \mathrm{~mL}$ of methylene was filtered through the modified fiber several times until complete saturation of the filter. The concentrations that has been tested were 1000, 850, 650, 500, 300 and $200 \mathrm{ppm}$. (3) $\mathrm{Q}_{\mathrm{e}}$ was determined and $\mathrm{C}_{\mathrm{e}} / \mathrm{Q}_{\mathrm{e}} \mathrm{vs} \mathrm{C}_{\mathrm{e}}$ and $\mathrm{LnQ}_{\mathrm{e}} \mathrm{vs} \mathrm{LnC}_{\mathrm{e}}$ were plotted. The experimental results of retention capacities obtained for different sizes of fibers modified and unmodified and the captured mass by gram of fibers were calculated and summarized in Table 4. 
Table 4. Experimental results of retention capacities obtained for different sizes of modified and unmodified fibers. Removed methylene blue (mg) by

\begin{tabular}{ccccccc}
\hline Passages & $\begin{array}{c}\text { XL fibers } \\
(\mathrm{mm}) \\
\text { each passage }\end{array}$ & $\begin{array}{c}100 \mu \mathrm{m} \text { fibers } \\
\text { each passage }\end{array}$ & $\begin{array}{c}\text { by } 50 \mu \mathrm{m} \\
\text { fibers each } \\
\text { passage }\end{array}$ & $\begin{array}{c}\text { modifed XL } \\
\text { fibers }(\mathrm{mm}) \\
\text { each } \\
\text { passage }\end{array}$ & $\begin{array}{c}\text { modifed } \\
\text { fibers } 100 \\
\mu \mathrm{m} \text { each } \\
\text { passage }\end{array}$ & $\begin{array}{c}\text { modifed } \\
\text { fibers } 50 \mu \mathrm{m} \\
\text { each passage }\end{array}$ \\
\hline 1 & 48 & 49 & 49.5 & 47.5 & 50 & 50 \\
2 & 43 & 47 & 48 & 46.5 & 49 & 49.75 \\
3 & 35 & 46 & 47.5 & 46 & 48.5 & 49.65 \\
4 & 30 & 44 & 45 & 44 & 48.5 & 49.6 \\
5 & 28 & 42 & 44.5 & 35 & 48 & 49.5 \\
6 & 22 & 42.5 & 43.5 & 31 & 47 & 49.5 \\
7 & 18 & 40 & 30 & 26 & 30 & 47 \\
8 & 15 & 28 & 25 & 16 & 20 & 45 \\
9 & 12 & 20 & 22 & 16 & 15 & 37 \\
10 & 10 & 15 & 20 & 12 & 15 & 35 \\
11 & 10 & 15 & 20 & 10 & 15 & 35 \\
Total removed & 271 & 356.5 & 395 & 330 & 381 & 500 \\
mass & & & & & & \\
Total removed & 13.5 & 17.8 & 19.75 & 16.5 & 19.05 & 25 \\
mass per g of & 13.5 & & & & & \\
fibers & & & & & & \\
\hline
\end{tabular}

Langmuir and Freundlich plots are presented in Figure $7 \mathrm{a}$ and $7 \mathrm{~b}$ respectively. For both isotherms, the estimation of adsorbed quantities of methylene blue are fitted. In the two models Freundlich and Langmuir, the amount of dye absorbed by fibers provides acceptable linearity which confirms the accuracy of our experimental results.
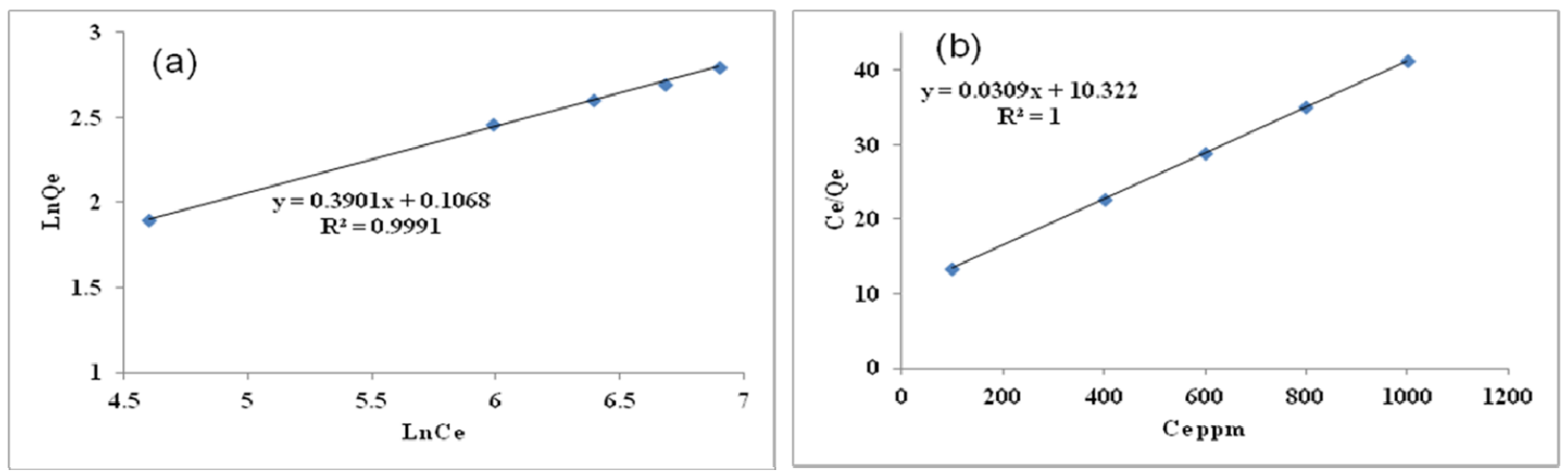

Figure 7. (a) Adsorption Freundlich isotherm modified fibers 50 microns, (b) adsorption Langmuir modified fibers 50 microns (the values $850 \mathrm{ppm}$ and $750 \mathrm{ppm}$ were averaged by the value of $800 \mathrm{ppm}$ )

\section{Discussion}

Georgiev et al. (2012) has found that the removal of $\mathrm{Cu}(\mathrm{II}), \mathrm{Zn}$ (II), $\mathrm{Cd}(\mathrm{II})$ and $\mathrm{Pb}$ (II) ions in aqueous solutions through synthetic zeolite was lower than $20 \mathrm{mg} \mathrm{g}^{-1}$ even after 20 minutes of contact time. Moreover, Murugesan 2006, has found that the capacity of removal of Arsenic III and Arsenic V by fungal biomass were1.11 and 4.95 $\mathrm{mg} / \mathrm{g}$ respectively. The modification of fibers by SDS showed an enhancement of the removal capacity compared to unmodified fibers and previopusly reported work (Murugesan, 2006; Tangahu, 2011; Georgiev, 2012). The removal mechanism likely involves complexation by chemical functions of fibers and adsorption by electrostatic 
Vander Waals interactions. The new aspect of the reported method here is its capability to have a dual role in the removal of heavy metals by complexation mechanism, and removal of oganic pollutants through the hydrophobicity of the SDS chains. Removal of methylene blue from polluted water changed with the $\mathrm{pH}$ solution, and the optimum removal efficiency was obtained at $\mathrm{pH}$ 6.5. Furthermore, removal efficiency increased significantly with the decrease in fiber size. Freundlich and Langmuir isotherms were established and described the removal process indicating favorable elimination of methylene blue from polluted water.

\section{Declaration of Interest}

Authors have no conflict of interest, in particular no financial, consulting and personal relationships with other people or organizations that could influence (bias) the author's work.

\section{References}

Addaou, A., Laajeb, A., Lahsini, A., Bentama, J., \& Rodriguez, M. A. (2012). Study of the combining adsorption-microfiltration process for the treatment of coloured waters. Boletín de la Sociedad Española de Cerámica y Vidrio, 51(3), 165-168. http://dx.doi.org/10.3989/cyv.242012

Aygun, A., Yenisoy-Karakas, S., \& Duman, I. (2003). Production of granular activated carbon from fruit stones and nutshells and evaluation of their physical, chemical and adsorption properties. Microporous and Mesoporous Materials, 66(2-3), 189-195. http://dx.doi.org/10.1016/j.micromeso.2003.08.028

Bai, R. S., \& Abraham, T. E. (2001). Biosorption of Cr (VI) from aqueous solution by Rhizopus nigricans. Bioresource Technology, 79(1), 73-81. http://dx.doi.org/10.1016/S0960-8524(00)00107-3

Blin, J-L., Stébé, M-J., \& Roques-Carmes, T. (2012). Use of Ordered Mesoporous Titania with Semi-crystalline Framework as Photocatalyst. Colloids and Surfaces A: Physicochemical and Engineering Aspects, 407, 177-185. http://dx.doi.org/10.1016/j.colsurfa.2012.05.029

Brunel, D., Cauvel, A., Di Renzo, F., Fajula, F., Fubini, B., Chiche, B., \& Garrone, E. (2000). Preferential grafting of alkoxysilane coupling agents on the hydrophobic portion of the surface of micelle-templated silica. New Journal of Chemistry, 24(10), 807-813. http://dx.doi.org/10.1039/b002945i

Chern, J., M., \& Wu, C. Y. (2001). Desorption of Dye from Activated Carbon Beds: Effects of Temperature, pH, and Alcohol. Water Research, 35(17), 4159-4165. http://dx.doi.org/10.1016/S0043-1354(01)00127-0

Dinand, E., Chanzy, H., \& Vignon, M. R. (1996). Parenchymal cell cellulose from sugar beet pulp: preparation and properties. Cellulose, 3(1), 183-188. http://dx.doi.org/10.1007/BF02228800

El-Sheikh, A. H., Sweileh, J. A., \& Saleh, M. I. (2009). Partially pyrolyzed olive pomace sorbent of high permeability for preconcentration of metals from environmental waters. Journal of Hazardous Materials, 169(1-3), 58-64. http://dx.doi.org/10.1016/j.jhazmat.2009.03.061

Eugenia, R., Pilar, R., Roberto, H., Javier, C., Ignacio, B.,\& Manuel, E. S. V. (2005). Journal of Chemical Technology and Biotechnology, 80(3), 291-298. http://dx.doi.org/10.1002/jctb.1192

Feng, Y., Zhou, H., Liu, G., Qiao, J., Wang, J., Lu, H., Yang, L., \& Wu, Y. (2012). Methylene blue adsorption onto swede rape straw (Brassica napus L.) modified by tartaric acid: equilibrium, kinetic and adsorption mechanisms. Bioresource. Technology, 125(0), 138-144. http://dx.doi.org/10.1016/j.biortech.2012.08.128

Garcia-Garcia, A., Gregorio, A., Franco, C., Pinto, F., Boavida, D., \& Gulyurtlu, I. (2003). Unconverted chars obtained during biomass gasification on a pilot-scale gasifier as a source of activated carbon production. Bioresource Technology, 88(1), 27-32. http://dx.doi.org/10.1016/S0960-8524(02)00266-3

Georgiev, D., Bogdanov, B., Hristov, Y., \& Markovska, I. (2012). The Removal of Cu (II) Ions from Aqueous Solutions on Synthetic Zeolite NaA. World Academy of Science, Engineering and Technology, 6, 1107-1111.

Ghosh, D., \& Bhattacharyya, K. G. (2002). Adsorption of methylene blue on kaolinite. Applied Clay Science, 20(6), 295-300. http://dx.doi.org/10.1016/S0169-1317(01)00081-3

Girgis, B. S., \& El-Hendawy, A. N. A. (2002). Porosity development in activated carbons obtained from date pits under chemical activation with phosphoric acid, Microporous and Mesoporous Materials, 52(2), 105-117. http://dx.doi.org/10.1016/S1387-1811(01)00481-4

Gulnaz, O., Kaya, A., Matyar, F., \& Arikan, B. (2004). Sorption of basic dyes from aqueous solution by activated sludge. Journal of Hazardous Materials, 108(3), 183-188. http://dx.doi.org/10.1016/j.jhazmat.2004.02.012

Gupta, V. K., Mohan, D., Sharma, S., \& Sharma, M. (2000). Removal of basic dye (Rhodamine B and Methylene blue) from aqueous solutions using bagasse fly ash. Separation Science and Technology, 35(13), 2097-2113. 
http://dx.doi.org/10.1081/SS-100102091

Hatt, J. W., Germain, E., \& Judd, S. J. (2013) Granular activated carbon for removal of organic matter and turbidity from secondary wastewater. Water Science and Technology, 67(4), 846-853. http://dx.doi.org/10.2166/wst.2012.644

Janos P., Buchtova, H., \& Ryznarova, M. (2003). Sorption of dyes from aqueous solutions onto fly ash. Water Research, 37(20), 4938-4944. http://dx.doi.org/10.1016/j.watres.2003.08.011

Kratochvil, D., \& Volesky, B. (1998). Advances in the biosorption of heavy metals. Trends in Biotechnology, 16(7), 291-300. http://dx.doi.org/10.1016/S0167-7799(98)01218-9

Low, K. S., \& Lee, C. K., \&Toh, B. L. (1994). Binding of Basic Dyes by the Algae, Chara aspera. Pertanika Journal of Science \& Technology, 2(1), 85-92.

Maurya, .N. S., Mittal, A. K., \& Cornel, P. (2008). Evaluation of adsorption potential of adsorbents: A case of uptake of cationic dyes. Journal of Environmental Biology, 29(1), 31-36.

Mikati, F. M., Saade, N. A., Slim, K. A., \& El Jamal, M. M. (2013). Biosorption of methylene blue on chemically modified chaetophora elegans alga by HCL and citric acid. Journal of Chemical Technology and Metallurg., 48(1), 61-71.

Murugesan, G. S., Sathishkumar, M., \& Swaminathan, K. (2006). Arsenic removal from groundwater by pretreated waste tea fungal biomass. Bioresource Technology, 97(3), 483-487. http://dx.doi.org/10.1016/j.biortech.2005.03.008

RajeshWarisivaraj, Sivakumar, S., Senthilkumar, P., \& Subburam, V. (2001). Carbon from Cassava peel, an agricultural waste, as an adsorbent in the removal of dyes and metal ions from aqueous solution BioresourceTechnology, 80(3), 233-235. http://dx.doi.org/10.1016/S0960-8524(00)00179-6

Rima, J., Assaker, K., Roques-Carmes, T., Mouneimne, A. H., \& El Ali, F. (2013). Developing a new carbonization process using high pressure and temperature to treat medical and municipality wastes for coal production. Journal of Applied Sciences Research, 9(3), 1666-1674.

Robinson, T., Chandran, B., \& Nigam, P. (2002). Removal of dyes from a synthetic textile dye effluent by adsorption on apple pomace and wheat straw. Water Research, 36(11), 2824-2830. http://dx.doi.org/10.1016/S0043-1354(01)00521-8

Senthilkumaar, S., Varadarajan, P. R., Porkodi, K., \& Subbhuraam, C. V. (2005). Adsorption of methylene blue onto jute fiber carbon: kinetics and equilibrium studies Journal of Colloid and Interface Science, 284(1), 78-82. http://dx.doi.org/10.1016/j.jcis.2004.09.027

Sing, K. S. W., Everett, D. H., Haul, R. A. W., Moscou, L., Pierotti, R. A., Rouquerol, J., \& Siemieniewska, T. (1985). Reporting physisorption data for gas/solid systems - with special reference to the determination of surface area and porosity. Pure and Applied Chemistry, 57(4), 603-619. http://dx.doi.org/10.1351/pac198557040603

Sricharoenchaikul, V., Pechyen, C., Aht-ong, D., \& Atong, D. (2008). Preparation and Characterization of Activated Carbon from the Pyrolysis of. Physic Nut (Jatropha curcas L.) Waste. Energy Fuels, 22(1), 31-37. http://dx.doi.org/10.1021/ef700285u

Tan, I. A. W., Ahmad, A. L., \& Hameed, B. H. (2008). Preparation of activated carbon from coconut husk: Optimization study on removal of 2,4,6-trichlorophenol using response surface methodology. J. Hazardous Materials, 153(1-2), 709-717. http://dx.doi.org/10.1016/j.jhazmat.2007.09.014

Tangahu, B. V., Abdullah, S. R. S., Basri, H., Idris, M., Nurina Anuar, N., \& Mukhlisin, M. (2011). A Review on HeavyMetals ( $\mathrm{As}, \mathrm{Pb}$, and $\mathrm{Hg}$ ) Uptake by Plants through Phytoremediation. International Journal of Chemical Engineering, 1-31. http://dx.doi.org/10.1155/2011/939161

Trens, P., Denoyel, R., \& Glez, J. C. (2004). Comparative adsorption of argon and nitrogen for the characterization of hydrophobized surfaces. Colloids and Surfaces A: Physicochemical and Engineering Aspects, 245(1-3), 93-98. http://dx.doi.org/10.1016/j.colsurfa.2004.06.031

Tsai, W. T., Chang, C. Y., Lin, M. C., Chien, S. F., \& Sun, H. F., \& Hsieh, M. F. (2001). Adsorption of acid dye onto activated carbon prepared from agricultural waste bagasse by $\mathrm{ZnCl}_{2}$ activation, Chemosphere, 45(1), 51-58. http://dx.doi.org/10.1016/S0045-6535(01)00016-9.

Tseng, R. L., Wu, F. C., \& Juang, R. S. (2003) Liquid-phase adsorption of dyes and phenols using 
pinewood-based activated carbons. $\quad$ Carbon, $\quad 41(3), \quad 487-495$. http://dx.doi.org/10.1016/S0008-6223(02)00367-6

Yalcin, N., \& Sevinc, V. (2000). Studies of the surface area and porosity of activated carbons prepared from rice husks. Carbon, 38(14), 1943-1945. http://dx.doi.org/10.1016/S0008-6223(00)00029-4

Zimny, K., Roques-Carmes, T., Carteret, C., Stébé, M. J., \& Blin, J. L. (2012). Synthesis and Photoactivity of Ordered Mesoporous Titania With Semicrystalline Framework. Journal of Physical Chemistry C, 116(11), 6585-6594. http://dx.doi.org/10.1021/jp212428k

\section{Copyrights}

Copyright for this article is retained by the author(s), with first publication rights granted to the journal.

This is an open-access article distributed under the terms and conditions of the Creative Commons Attribution license (http://creativecommons.org/licenses/by/3.0/). 